\title{
Exploring the patriarchal limits of liberal democracy. Spanish feminist movement's shift from institutional to protest struggle
}

\author{
Explorando los límites patriarcales de la democracia \\ liberal. El cambio del movimiento feminista español \\ de la lucha institucional a la de protesta
}

\author{
DANIEl ROMERo-PoRTILLO* \\ Sociólogo. Universidad Pablo de Olavide, Sevilla \\ ORCID ID: 0000-0002-2852-9323 \\ LAURA MÁRquEZ BoNo* \\ Socióloga. Universidad Pablo de Olavide, Sevilla \\ ORCID ID: 0000-0002-0242-0194
}

Recibido: $2 / 4 / 2020$

Aceptado: $24 / 11 / 2020$

doi: https://doi.org/10.20318/femeris.2021.5980

\begin{abstract}
March protests have recently become one of the most salient political phenomena. In Spain, the rate of participation and the nature of its demands clearly depict a strong and organized movement highly critical of how the democratic regime itself serves women interests and needs. Thus, after reviewing how feminist theory have previously dealt with liberal democracy theory and its concept of citizenship, it is explored whether Spanish feminist movement supports or not liberal democracy. To accomplish that goal, statistical analysis is developed using data from opinion barometers 3173 (April 2017) and 3210 (April 2018) by Spanish Center for Sociological Research (CIS). Descriptive graphics and regression models are used to test the hypothesis. Strong evidence is found on the relationship between the increase of protest politics and feminist ideologization, especially among young women. Meanwhile, slighter but actual evidence is found on whether participating in feminist protests leads to either non-institutional feminist electoral alternative or abstention, depending on self-political effectiveness. Hence, the increase in political strength on the Spanish feminist movement has not implied a disengagement of liberal democracy although grievances and obstacles to participation this political system impose to women. Instead, it has led to a struggle for radical democracy supported by feminist disregarding age or left-right ideological self-placement.

Keywords: feminism, political participation, liberal democracy, protest, 8th of March.

Resumen. Las protestas del 8 de marzo se han convertido recientemente en uno de los fenómenos políticos más destacados. En España, la dimensión y la naturaleza de las demandas del movimiento indican un fuerte y organizado movimiento enormemente crítico con cómo el régimen democrático en sí sirve a los intereses y a las necesidades de las mujeres. Por ello, tras
\end{abstract}

\footnotetext{
*drompor@upo.es

**auramarquezbono@gmail.com
} 
revisar cómo la teoría feminista ha tratado con anterioridad la teoría de la democracia liberal y su concepto de ciudadanía, se explora si el movimiento feminista español da apoyo o no a la democracia liberal. Para acometer ese objetivo, se desarrollan análisis estadísticos haciendo uso de los barómetros de opinión 3173 (abril 2017) y 3210 (abril 2018) del Centro de Investigaciones Sociológicas (CIS). Para comprobar las hipótesis se emplean gráficos descriptivos y modelos de regresión. Se ha encontrado firme evidencia sobre la relación entre el aumento de la política de protesta y de la ideología feminista, especialmente entre mujeres jóvenes. Mientras, efectiva pero menos sólida evidencia se halla en cuanto a si participar en protestas feministas lleva tanto a opciones electorales de feminismo no institucional o a la abstención dependiendo de la consideración de propia efectividad política. Por consiguiente, el incremento de la fuerza política del movimiento feminista español no ha conllevado la ruptura con la democracia liberal a pesar de los agravios y obstáculos a la participación que este sistema impone a las mujeres. En cambio, sí ha conllevado a la lucha por una democracia radical apoyada por las feministas sin importar su edad o posicionamiento ideológico tradicional (izquierda-derecha).

Palabras clave: feminismo, participación política, democracia liberal, protesta, 8 de marzo.

\section{Introduction}

March 8, 2018 the greatest feminist demonstration and strike took place in Spain. This protest, the second year in a row, was outstanding internationally reaching 5 million demonstrators (Fraser et al.,2018; Watkins, 2018; García et al., 2018). This political phenomenon had quantitative and qualitative specificities. Firstly, demonstrations throughout the whole country took place in cities and many towns. It was due reticulate organization's capacities and efforts of feminist movement through commissions out of tutelage or co-optation of parties, unions, media... but support of certain institutions such as Madrid and Barcelona majors (Watkins, 2018; García et al., 2018). Likewise, it forced the main political actors to place themselves either respectful support by progressives or interfering support by liberals, or refusal from conservatives and government (Balaguer Callejón, 2019)

Secondly, it was a fourfold strike stopping work, education, care and consumption under the claim "together we are more" (Campillo, 2019; Moriana Mateo, 2018; García et al., 2018). Issues like inequalities in productive and reproductive work, bodies' hipersexualization, violence or institutional deprotection perception favored this fourfold protest (García et al., 2018; Balaguer Callejón, 2019). Moreover, the most impressive aspect is that it happened despite the lack of institutionalization, structure, funding and professionalization of representatives (Campillo, 2019).

What makes 2018 strike different is its success, which stems from the preparation process starting since the 2017 strike (Campillo, 2019). This process overcame organizational weaknesses through successful coordination of decentralized committees and the ability of articulating and alliating plural demands from different feminist branches. It also fostered an intergenerational alliance between feminists from the seventies and young feminists who became politicized during the anti-austerity protest cycle (Portos, 2019; Campillos, 2019). This preparation was strongly backed by dynamics generated in the protest cycle both social mobilization against cuts and austerity (Indignados, Ties in defense of public services...) and feminist mobilizations against regressive abortion le- 
gislative bill and gender violence. Finally, international trend generated by \#MeToo movement reinforced the reaction against cases of sexual abuse and rapes (Campillo, 2019; Fraser et al., 2018).

Beyond electoral results, the most relevant aspect of 2018 strike was its impacts on collective definition of feminist political subject along with its demands, interests and grievances. Debates on protest legitimacy, role of women and men in the strike, goals and sense of feminist struggle took place at public opinion and media (García et al., 2018). In these debates, feminist movement set agenda and built new hegemonic gender conscience joining claims from mainstream women with vulnerable ones and in doing so, attaching social support and unity of action (Moriana Mateo, 2018; Balaguer Callejón, 2019). That is, precariousness and deprotection resulted a plural feminist subject and a political program based on care and protection (Balaguer Callejón, 2019; Centella Gómez, 2018). Nevertheless, some scholars notice the gain on relevance also had negative consequences, mainly media reinterpretation of proposals and prioritization of inequalities on productive work rather than on political and economic system as a whole (Fraser et al., 2018; García et al., 2018)

Despite the above, the most puzzling aspect of this political protest is the shift of Spanish feminist struggle from institutional to protest. Feminist movement in Spain developed protest cycle since the beginning of democratic political transition struggling for women's equality (specifically abolishing discriminative laws) and progressive policies on sexuality, motherhood... (Gahete Muñoz, 2017). Mobilization process lasted until the '80s when feminism split between majoritarian institutional feminists and minoritarian grassroots movement. Channelized through associationism, Spanish feminism had debates on equality-difference, electoral participation and the relationship with formal political arenas under liberal democratic regimes (Moriana Mateo, 2018; Gahete Muñoz, 2017).

Therefore, the emergence of anti-patriarchal feminism, more radical than institutional branch, is the most shocking phenomenon in the gender equality struggle in the last four decades. In terms of political systems theory by David Easton (1965) the outputs produced (namely gender equality policies and violence protection laws) by Spanish political system would be no longer satisfying feminist movement's demands. Given that, the logical consequence is the end of support of women's movements (previously defined as institutional feminism) to formal democratic institutions and the emergence of more defiant inputs and radical demands. Thus, this political phenomenon naturally connects to a classical political theoretical debate: to what extent liberal democracy is able to respond to women and feminism concerns? So, this article will approach the research question on whether feminists are no longer supporting liberal democracy or struggling to deepen this democratic regime through other kinds of political participation and engagement.

To obtain that goal this paper is organized as follows. Second section approaches the feminist critiques to liberal conceptions of democracy and citizenship. Third section states how empirical inquiry will be conducted to answer the research question. Fourth section analyzes empirical data. Lastly, discussion of results and conclusion to the study are exposed. 


\section{Literature Review}

\section{On the feminist critique to liberal democracy}

Feminist questioning of current political regimes addresses even beyond liberal democracies: modern liberalism and Enlightenment. In a representative classic work Carole Pateman (1988) states the pact in which our modern societies are built on is both social and sexual, although the sexual part has been generally omitted. That is, our social contract is undoubtedly built on a patriarchal social order. Traditional perspective on social contract was interpreted as emancipatory since it allowed evolving from the uncertain and insecure natural freedom to the civic and civilized freedom provided by the rule of government. However, social contract is not only based on free relations among men but also necessarily based on their (male) equal right to oppress politically and access sexually to women - the patriarchal right (Pateman, 1988). Nonetheless, this punctualization is commonly omitted due to the success of contract theorists on equating paternal (patriarchal) order to the nature of relations and ties occurring before the social contract. So, in spite of social contract that liberated humankind from traditionalist-paternal oppressions, the break of traditional ties did not liberate women from subjection to men.

As Pateman stated (1988), sexual half of contract organizing modern societies has been unattended not only by liberals but also socialists and even some feminist thinkers. The long-standing debaters in fact share the assumption about the political irrelevance of the private-public division. These currents of thought share the idea people own themselves as individuals, but patriarchally conceived individuals. In particular, the kind of property negotiated in a sexual contract is a special one: women. The patriarchal contractual relationships are crucially affected by the definition of characteristics needed to participate in contracts: since women are not considered to hold natural freedom but subjected to men, this did not allow them to transit to civil freedom nor hold the capacity to pact. Thus, the exclusion of women from the exercise of freedom stems from the sexual difference and is consolidated through social and legal norms. Besides, differences have been naturalized over time in order to justify the consequent oppression.

Turning to current democracies debate, feminist critique addresses the inexistence of equal conditions and impossibility for women to exercise an active democratic participation within liberal democracy (Philips, 1992). In spite of liberal and democratic thought informed feminism, liberal democracy has never fulfilled nor served to women interests on exercising democratic power. Critique first claimed for a horizontal participatory democracy but then developed to an inclusive perspective aimed to achieve an equal situation and a political engagement providing women the opportunity to take part in decision-making processes (Philips, 1992). This must also take into account equal participation is bounded without socioeconomic equality effectively supporting this democratic participation.

Nonetheless, liberal democracies, as based on equality principle, have always understood differential treatments as contrary to democratic. Nonetheless, Philips (1992) 
argued what this approach ignores is that equality and heterogeneity are not the opposite but in fact, to gain actual equal conditions, differences must be taken into account ${ }^{1}$. Philips (1992) denied the binary framework of taking society entirely as a whole or as a constellation of individuals. She advocates giving saliency to dimensions such as gender dramatically affecting democracy. In fact, liberal democracies are based in many partisans' divisions but have traditionally not accepted gender differences as part of these groups deserving representation. Nevertheless, the debate evolves to consider two extreme positions: whether women must integrate their demands as a sort of group of interests stressing absolutely their differences or engage political sphere neutralizing gender dimension. Philips finally states the empowerment of women as an oppressed social group can only be obtained by recognizing them as a specific group. The debate on equality-difference feminism will be approached in depth in the next section.

Current feminist critiques on liberal democracy address two realms: women participation as citizens and as representatives. On female citizens' participation they criticize the merely passive political participation liberal democracies enable and how already defined women's preferences are assumed. Because of that, feminist thought has adhered to participatory democracy claim. Menser (2018) links it to the debate on the feasibility and desirability of Maximal Democracy against representative liberal democracy. However, Philips (1992) points out contradictions in participatory democracy: basing on disagreement, it is strongly time-demanding not making it possible for many women to engage. Nonetheless, she agrees with Pateman in solving these problems redistributing care duties and di-gendering division of labor: political rights are useless for women without social-labor rights (Pateman, 1992). In the same vein, Menser (2018) mentions ecological oriented feminism's proposal of a social reproduction participatory democracy that could democratize not only productive work among humans, but also reproductive work regarding ecological systems and overall, through a plural relationship with the state.

Therefore, limitations to women's political participation without solving social production inequality lead to a paradoxical situation: either the less demanding characteristics of liberal democracy somehow permit women to participate ineffectively in politics, or they cannot participate effectively in participatory democracy. Undoubtedly, this implies high degrees of disaffection and lead feminist movement once again to resolve the dilemma on refusing or democratizing liberal democracy.

On female representative's participation, the debate is on institutional and electoral reforms that have been implemented for decades to increase the number of women in representative institutions and their (in)sufficiency to engage women politically through their inclusion in current political institutions (Cornwall and Goetz, 2005). Opposed positions debate whether women should be considered as autonomous political communities intrinsically defending their own interests. Even in times of struggle for suffrage, women were defined as an autonomous category in a reactive manner caused by their

\footnotetext{
${ }^{1}$ Current feminist theory or public policies usage of the concept gender mainstreaming may be an intellectual heritage of this sort of normative positions.
} 
exclusion from democratic process already defined them negatively (Caraway, 2004). The institutional debate regards affirmative actions to increase female representation such as reservations or quotas. The former considers sexual difference needs an autonomous consideration whereas the latter does not.

Nonetheless, although this increase has been a worldwide concern to democratic and feminist movement, there is no evidence linking it to feminist decision-making processes, policies in favor of women or a rise in parties' accountability on gender equality (Cornwall and Goetz, 2005). Empirical studies point out the inclusion of women in democratic representative institutions is not caused by the existence of a liberal democratic regime. Even in non-democratic countries one can find more female representatives, despite having a non-real capacity of exercising power. That is due to the fact that inequality is not determined by sex itself, but by political apprenticeship: the inputs and the ways that lead a citizen to become a representative. In the absence of proper accountability and the determinant presence of party candidates' selection, elected women representatives might not respond to female electorate's demands (Cornwall and Goetz, 2005). Representatives are trained and then selected in exclusive arenas where women are more unlikely to enter or express themselves an if so, women are instructed under a political style and apprenticeship discouraging root feminist activists to enter in representative institutions. So, women representatives respond to party dynamics needs rather than gender-based demands.

Therefore, filling representative spaces with female bodies disregarding gender equality issues might be useless if not counterproductive since ruling parties might feel legitimated as achieving fake women political inclusion (Cornwall and Goetz, 2005). Thus, the feminist goal is not essentially to extend number of female representative but to deepen the democratization and articulate demands on gender injustices in every social realm including political and private spheres. In fact, what evidence does show is that the democratization process occurring in consolidated liberal democracies are substantially increasing actual representation of women (Fallon et al., 2012).

In comparison to traditional political arenas, new democratic spaces within civil society enable generation of new feminist leaderships and new pathways towards political institutions. Recent opening and stretching of decision-making spaces have allowed feminist organizations to improve their influence in policy processes, permitted the access of feminist leader not instructed under masculine logics and finally, engendered liberal democracies (Cornwall and Goetz, 2005). These new democratic spaces outside traditional political arenas are named by Nancy Fraser (1992) subaltern counterpublics. Anyway, female political agency would continue being constrained by its own precariousness and subjection to the dynamics of formal political arenas and masculine political culture. Hence, new spaces need to not reproduce traditional errors but to facilitate political apprenticeship making possible articulate political positions challenging patriarchy in liberal democracy (Cornwall and Goetz, 2005). In sum, democratization of democratic systems needs to take into account other political democratic spaces where women are better included (politically and materially) to participate. 


\section{On the feminist critique to liberal citizenship}

Political equality is not restricted to the institutional dimension of liberal democracy. Material conditions and care duties culturally imposed on women make them also much more difficult to exercise their citizenship. To tackle this unbalanced situation not only women's presence in decision-making places must be fostered but also sexual division of productive and reproductive labor should be eradicated. The reason for this unbalanced relationship is how citizenship and its defining characteristics were built on "a gendered division of labor" and therefore, freedom and equality standing on citizen status cannot generate a completely egalitarian society (Philips, 1992). It can be linked to Pateman's (1988) theory on sexual contract: civil society emerging from social contract distinguished between public and private spheres, depoliticize the latter but keep applying patriarchal rights in both spheres, just in distinct manners. Patriarchy directly confronts citizenship as a patriarchal order implies ascribed status such as the fixed subordination of women. So, civil society might only be post-patriarchal when an inclusive equal private sphere emerges.

In spite of citizenship theorization is centuries old, the debate on how men configured in male ways citizenship as well as defining characteristics of democracy like freedom, rights, equality and participation, is extremely more recent. Critical discourses on liberal citizenship typically aim to deepen and broaden the traditional conception of citizens in order to engage excluded groups. This concern on women's inclusion and the gendered power relations behind liberal citizenship has only recently been revealed. In the following paragraphs we review current feminist debates on citizenship critics to classical perspectives: liberal and communitarianism.

Liberal feminists struggle for women's rights as citizenship without "challenging dominant liberal models of citizenship" shaped by patriarchy and in so do not accept female characteristics and subordinate them (Mouffe, 2013). In contrast, critical feminism defends ethics of care including reproductive rights and arguing that the private field of politics also matters against liberal ethics of justice that place (male) citizen's rights as key factor (Lister, 1997; Mouffe, 2013). The public assimilation of women to male citizenship, relegating to the private sphere any particularity that does not identify with the patriarchal citizenship, is opposed to the importance given to the family in the face of liberal individualism.

Critical feminists share with communitarianism the critique to the constraint of liberal citizenship to the legal status providing norms to protect individuals from the exercise of power, disregarding political participation and common goods as well as the debate on duties and defense of the subjection of individuals to common goals (Lister, 1997; Mouffe, 2013). This collective perspective links with the active participatory role of citizens both defend. Nonetheless, communitarianism is not aware of how universal concepts like common good and general will does not transcend differences among social groups but reinforce the exclusion of disadvantaged groups (Lister, 1997). So, it lacks the plural approach a modern democratic regimen needs to satisfy multiple demands. 
Critical feminists defend to transcend both liberal and communitarian perspectives due to their limits on individualism and universalism not taking into account gender mainstreaming implications such as women's differential demands and their needs on care and protection (Lister, 1997; Mouffe, 2013). This is undoubtedly related to the equality-difference debate within feminism also called the Wollstonecraft dilemma: equality suppose accepting the patriarchal citizenship, but difference implies accepting the subjection and subordination under patriarchy (Mouffe, 2013). Pateman (1989) addresses the dilemma with the sexually differentiated concept of citizenship recognizing women their civic equal status and, at the same time, their differential characteristics as women. Nonetheless, Mouffe (2013) denies that Pateman's definition of a bi-gender citizen solves the dilemma since it still bases sexual difference on supposedly women-defining characteristics like motherhood. Instead, Mouffe defends the existence of two universalities and refuses strategies of othering or defaming women. By doing so, she neither considers neutralgender citizenship nor need to define women essentially by their gender.

Concern on anti-essentialist approach to citizenship, not based on womanhood unity around a priori interests, does not deny the possibility of constructing political common action formulating broad political demands within a radical democratic proposal. Critical feminism urges to distinguish being a citizen either liberal or communitarian, requiring fitting some standards and forced to participate, with acting as a citizen, a flexible approach from feminist agency theory that do not deny citizenship to women because of their patriarchal constraints and obstacles to their political engage (Lister, 1997; Mouffe, 2013). That is to say, women must generate alliances among multiple subordinated subjects rather than attend to groups differentiated demands or homogenize all the oppressed by overlooking their diversity and asymmetric power relations.

The equality-difference debate does not realize that the struggling for equality in an inegalitarian society needs to take into account that equality is a privileged status achieved by a few, and because of that, identity politics are crucial to reach a real equality in a democratic system. Iris M. Young (1990) defined "group differentiated citizenship" to criticize the typology of public sphere conceived in liberal democracies pretends to represent the general will and hence, to politicize it and generate heterogeneous public spheres in which subordinated groups can express themselves. On the contrary, anti-identity politics supposedly claiming for difference have been developed not only from conservatives but also different branches of the left alleging it prioritizes individuals, differentiated groups and partial political actions and also defends the definition of oppressed groups by their powerlessness and subjection making impossible claims on universal struggle towards emancipation and reinforcing divided spaces of regulation (Bickford, 1997). In contrast, feminism respond the universalistic struggle for equality is based on a non-neutral masculine citizenship which not satisfy the interests of non-dominant groups.

Nonetheless, at the same time, homogeneous conceptualization of women provided by difference feminism or communitarianism is counterproductive for radical feminist politics, since it does not reinforce the position of citizen of women and denies its plurality in social relations. For instance, Mouffe (2013) criticizes Young and Pateman's views as es- 
sentialist approaches relegating women to private sphere and defining them as essentially subordinated. Hence, only non-essentialist perspectives enable to articulate links among subordinated social groups and build citizenship as an identity asserting both equality and liberty (Mouffe, 2013). Therefore, the contraposition of equality to difference is indeed a false dilemma as there is no homogenous man nor woman to equate. The feminist citizenship is the one combining identity and egalitarian politics in an emancipatory way. That is to say, it defines women as oppressed groups not as victimhood and maintains their gender plurality and private individuality while exercising their collective political rights (Jalusic, 2002; Bickford, 1997).

Other debates have been developed through feminist critique to liberal citizenship. On the public-private spheres debate feminists defend the needs and interests of women are politically relevant demands rather than domestic issues conceived under patriarchal approach (Lister, 1997). They denounce this division has always been a gender division as defining public-male sphere as universalistic and rational whilst private-female as personal and emotional (Abowitz and Harnish, 2006). In doing so, they shift, negotiate and interrelate both spheres regarding sexual division of labor affects women inclusion in citizenship. Thereby, critical feminists transcend liberal demands of institutional changes as well as communitarian demands of enriching citizenship including differential female skills (Abowitz and Harnish, 2006). They place achievement of full political equality and recognition and appreciation of the difference between men and women as an equal central goal. Likewise, the recognition of differences between women themselves is a relevant critique to the malestream perspective conceiving women as a single category (Lister, 1997).

On the inclusion-exclusion debate, feminists state gendered dimension of exclusion is present in both liberal and communitarian theoretical and practical exercise; and specially they oppose to liberal multiculturalism. On one hand, Kymlicka (1995) defends the exercise of minority rights within a beneficial relationship with the majority regarding minorities' interests are not fixed nor objective and may not be liberal if they are imposed from traditional institutions. On the other hand, feminists propose the concept of trans-culturalism recognize group differences without simplifying groups to their cultural characteristics.

Positions of current feminist in these two debates do not mean the deny the advantages of universalist citizenship but it can only include disadvantaged groups if their particularities and diversity in general is recognized. Iris M. Young (1990) and Chantal Mouffe (2013) positions might converge in this kind of universalist perspective not implying false impartiality but a positive appreciation of differences within democratic system. This leads directly to the politics of accommodation of diversity within rights of citizenship such as the assertion of differences given by particular policies and legal protection to women.

\section{Research Design, Hypothesis \& Data}

This study departs from the assumption that voting and protest are not mutually exclusive but opposed ways of political participation. Because of that, we start depicting a 
shift of the feminist movement from participation through institutions to protest and how it can be related with a change in the support of the Spanish liberal democratic regime. That is to say, feminists observing either liberal democracy does not fulfil their needs, or they are not able to press and move forward their demands might disengage the political system. To explore this, we will start test whether the increase of the level of protest and feminist consciousness is empirically backed. Hence, (H1) we expect a considerable and parallel increase in the level of participation in strikes and demonstrations, as well as in the ideological self-identification as feminist.

Moreover, it has been exposed these two phenomena might be correlated: protesting citizens are closed to feminist ideology. So, (H2) concomitant relationships are expected among participating in strikes and demonstrations and identifying primary or secondary as ideologically feminists. It will not be the aim of this research to address whether ideologization leads one to participate politically or is participation what produces ideological socialization. In here, interdependence is assumed.

Once tested the actual relationship between feminism and protest politics, the main goal of this research is to explore the influence feminist ideology along with participating in protest and considering political participation within liberal democracy is effective on the engagement to Spanish democratic system. Therefore, (H3) we expect being feminist and taking part of protests is favoring electoral shift towards non-institutional feminist political party rather than democracy disengagement. Besides, (H4) we expect citizens considering themselves politically effective might also change their vote to these parties whereas not considering themselves political effective would lead to electoral absenteeism.

In order to test these research hypotheses secondary datasets elaborated by Spanish Centre of Sociological Research (CIS) will be analyzed. Specifically, four studies are chosen due to the nature of the specific questions they include on participating in protests and political effectiveness as well as the time they were conducted, before and after 8 March, 2018. Studies 3173 and 3210 include questions about taking part in demonstrations and strikes and were conducted in April 2017 and 2018. Studies 3156 and 3226 include questions about how effective people are participating in the formal political process of liberal democracy and were conducted in October 2016 and 2018. In addition, all studies include information about voting, ideology, socio-economic and socio-demographic circumstances.

\section{Results}

In Figure 1 we can observe a general increase in the participation in demonstrations and strikes occur between 2017 and 2018. Nonetheless, there are several patterns that deserve further attention. Demonstrations in 2017 seem similar among both women and men under 65 . However, the percentage of young women taking part in demonstrations in 2018 is much higher. On strikes, the trend in both years shows the younger the more one 


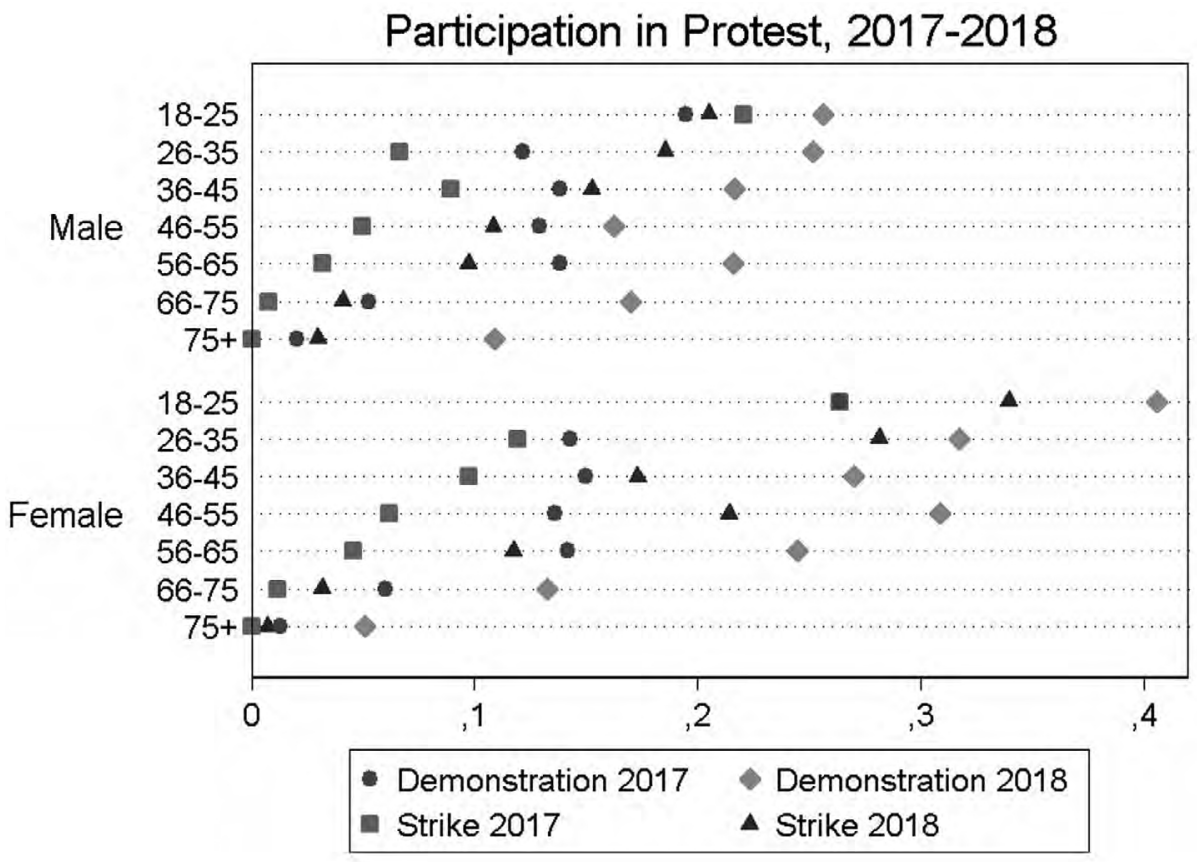

Figure 1. Increase of participation in protest by gender and age, 2017-2018. Own elaboration from CIS 3173 and 3210.

participates in. Nevertheless, once again young women reach the highest percentages and produce some gap even with young men.

In Figure 2 it can be observed the extreme difference between genders in identifying ideologically as feminists. Moreover, the increase of feminist ideologically aligned men is minimal in comparison to women. Therefore, the phenomena of growth of protest and feminist politics is mainly experience among women, especially the youngest.

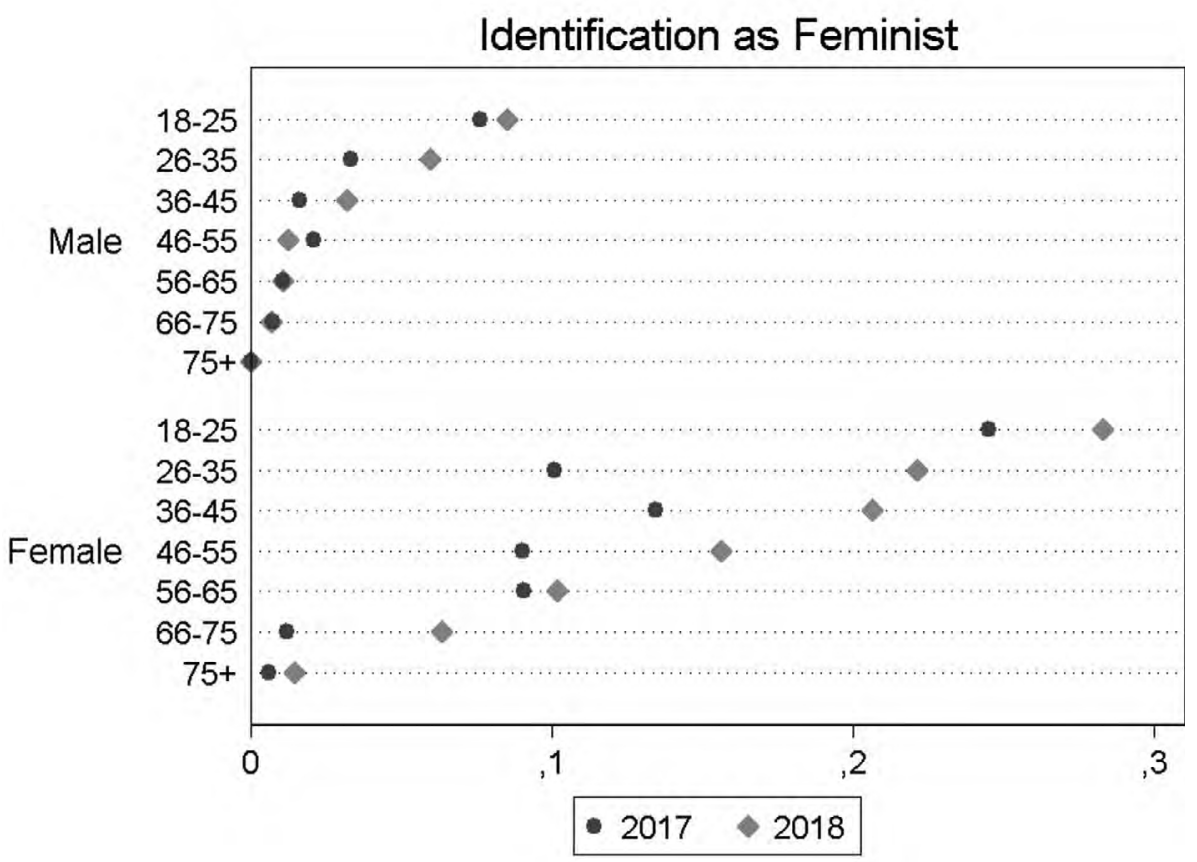

Figure 2. Increase of ideological identification with feminism by gender and age, 2017-2018. Own elaboration from CIS 3173 and 3210. 


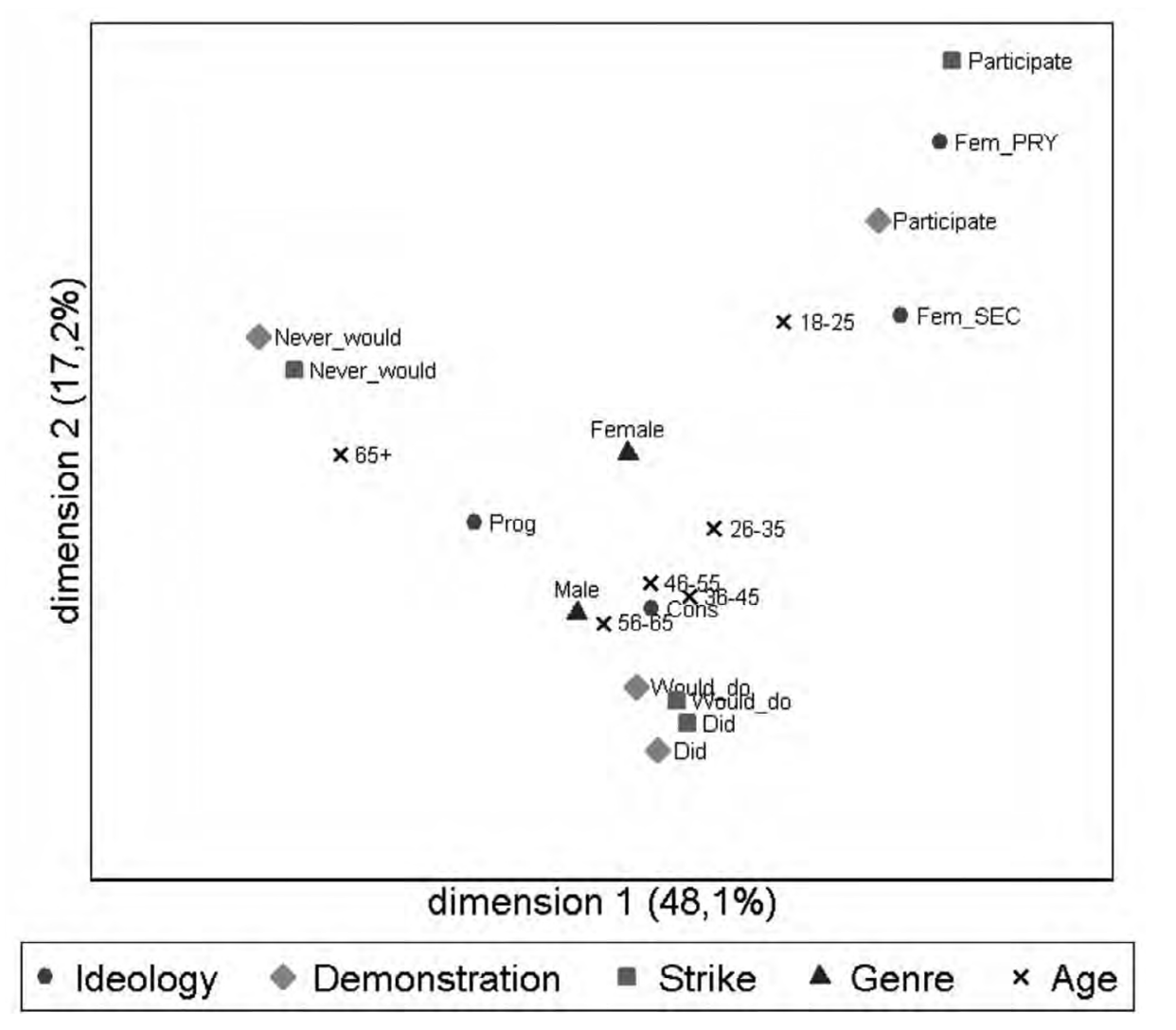

Figure 3. Multiple correspondence analysis plot relating protest and ideology, 2017-2018. Own elaboration from CIS 3173 and 3210.

To explore the possible concomitant relationship between these two political processes, we conduct a multiple correspondence analysis taking into account participation in protest, feminist ideology, age and gender. As a result, in Figure 3 is exposed a plot of every variable's categories coordinates. This technique has been chosen because it offers an intuitive measure of association among non-interval variables. There we can observe three distinct trends: young women tend to participate in present times and also to identify as feminists; older citizens are not open to the idea of protesting anyway; and finally, medium-age citizens with a higher proportion of men remember having taken part in protest or state they could do.

In order to explore whether feminists taking part of demonstrations and stakes feel no longer attached to liberal democracy a longitudinal comparison is developed on the preference for a democratic regime as well as on the opinions about anti-establishment, citizen and feminist's concerns. Figure 4 shows little changes have taken place in preferences for democracy except for an increase of this inclination in favour of democratic regime among feminists (as their ideology) who demonstrate and strike and also among feminists (as a secondary ideology) who demonstrate.

Figure 5 depicts the evolution of anti-establishment or anti-politics opinions among different types of feminist citizens. An overall decline of anti-establishment opinions is observed among citizens defining themselves feminist as their main ideology. In contrast, those who define themselves feminist as their secondary ideology and have participated 


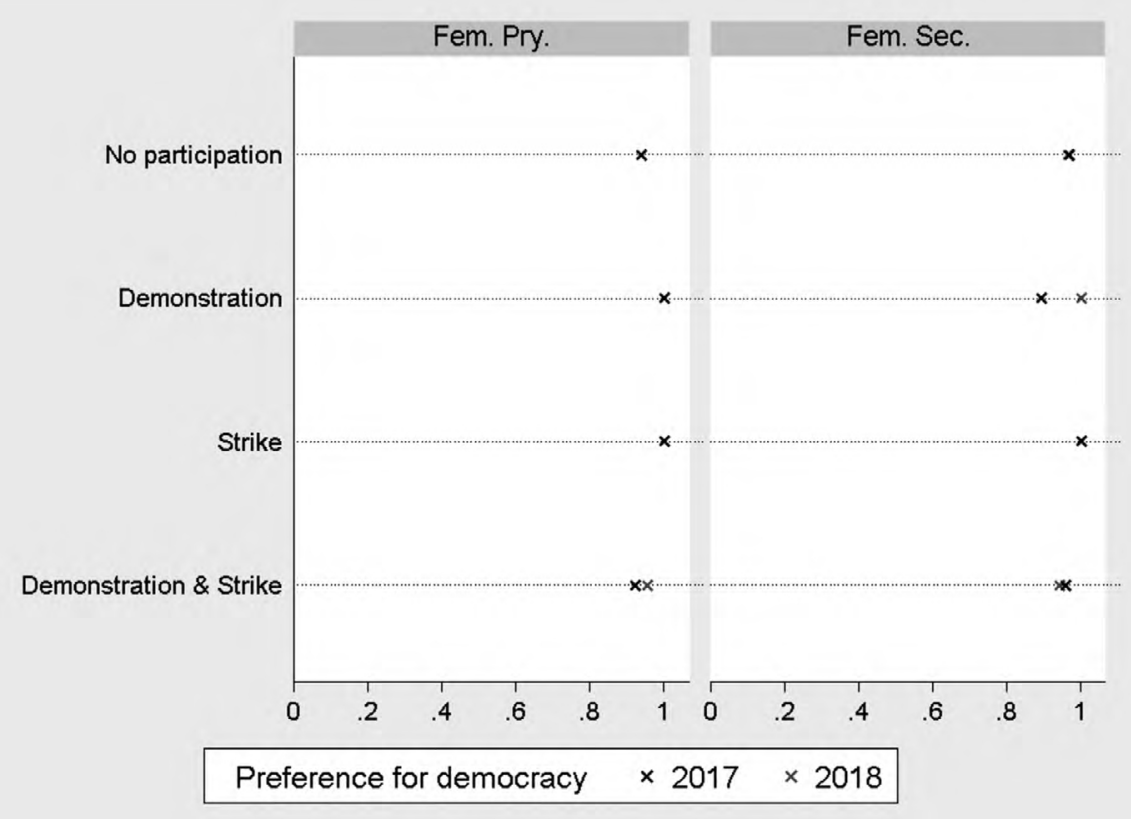

Figure 4. Evolution of preferences for democracy among feminist and political participation, 2017-2018. Own elaboration from CIS 3173 and 3210.

Figure 5. Evolution of opinions on anti-establishment concerns among feminist and political participation, 2017-2018. Own elaboration from CIS 3173 and 3210.

in demonstrations and strikes experience an increase in their concerns about corruption and politicians.

The evolution of citizens' concerns is depicted in Figure 6. There it can be observed no changes on these kind of concerns have occurred except for the great increase in concerns about Justice administration among those defining themselves feminist as a secondary ideology and participate in strikes. As stated previously, scandals about decisions made by judiciary on rape cases is likely to have boosted this concern. 


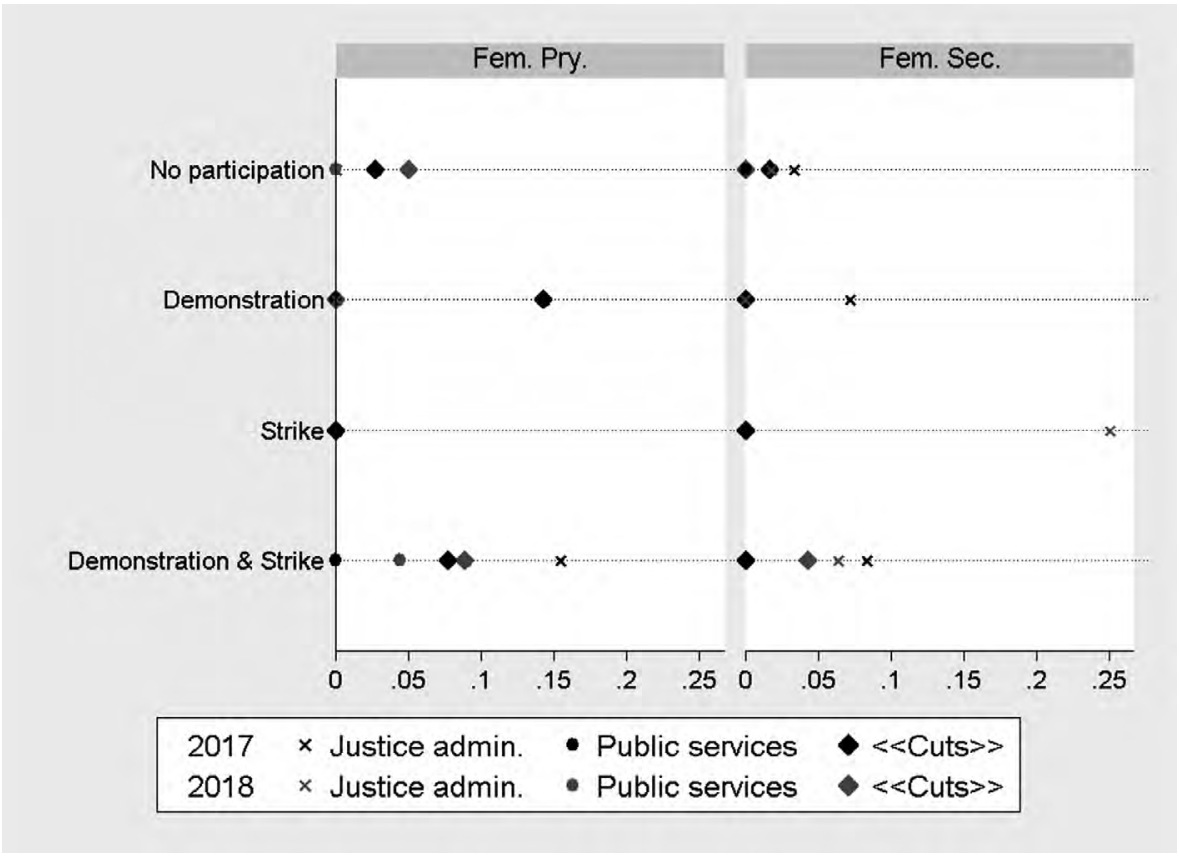

Figure 6. Evolution of opinions on citizens' concerns among feminist and political participation, 2017-2018. Own elaboration from CIS 3173 and 3210.

Lastly on the evolution of opinions among feminist citizens, Figure 7 shows the longitudinal evolution of feminist topics' concerns. Specifically, a clear increase since 2017 to 2018 of concerns about violence against women and women's problems is experienced by those defining themselves feminist as their main ideology. Meanwhile, the opposite evolution take place in those defining themselves feminist as their secondary ideology. Both trends take place among those participating in any kind of protests. The most likely interpretation is participating in feminist protests led citizens to feel more worried about social relevance of those two topics.

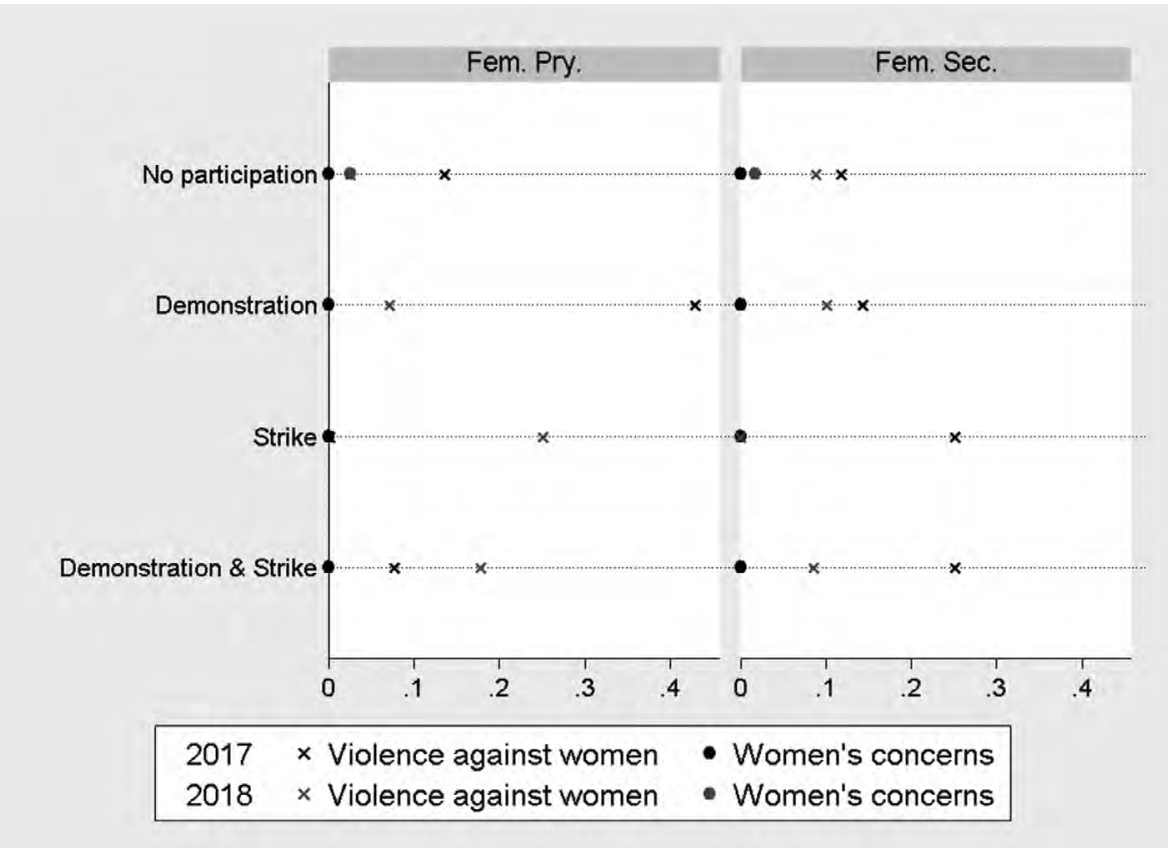

Figure 7. Evolution of opinions on feminist concerns among feminist and political participation, 2017-2018. Own elaboration from CIS 3173 and 3210. 
In Figure 8, multinomial logistic regression model's coefficients are shown. This regression is run over a four-categories dependent variable: abstentionism, voting UP, PSOE or other political parties. This decision is made in order to represent the fourfold positions that can be held from feminist movement. That is, abstentionism would mean they disengage liberal democracy; voting UP would mean shifting electoral decision towards a more radical feminist option; voting PSOE would mean keep voting institutional feminist; whilst voting other political parties is used as base outcome category in the model. Two new variables are included in this model: ideological auto-positioning and preference on State territorial organization (not shown in figures). The former is included to offer control to electoral decisions. The latter is included to monitor the other protesting phenomenon shocking Spanish politics: the national-territorial conflict.

What we find in Figure 4 is UP is obtaining significantly more votes from citizens taking part in demonstrations (not strikes) and considering themselves feminists. Meanwhile, PSOE as representative of classical institutional feminism is significantly losing electoral support from this profile.

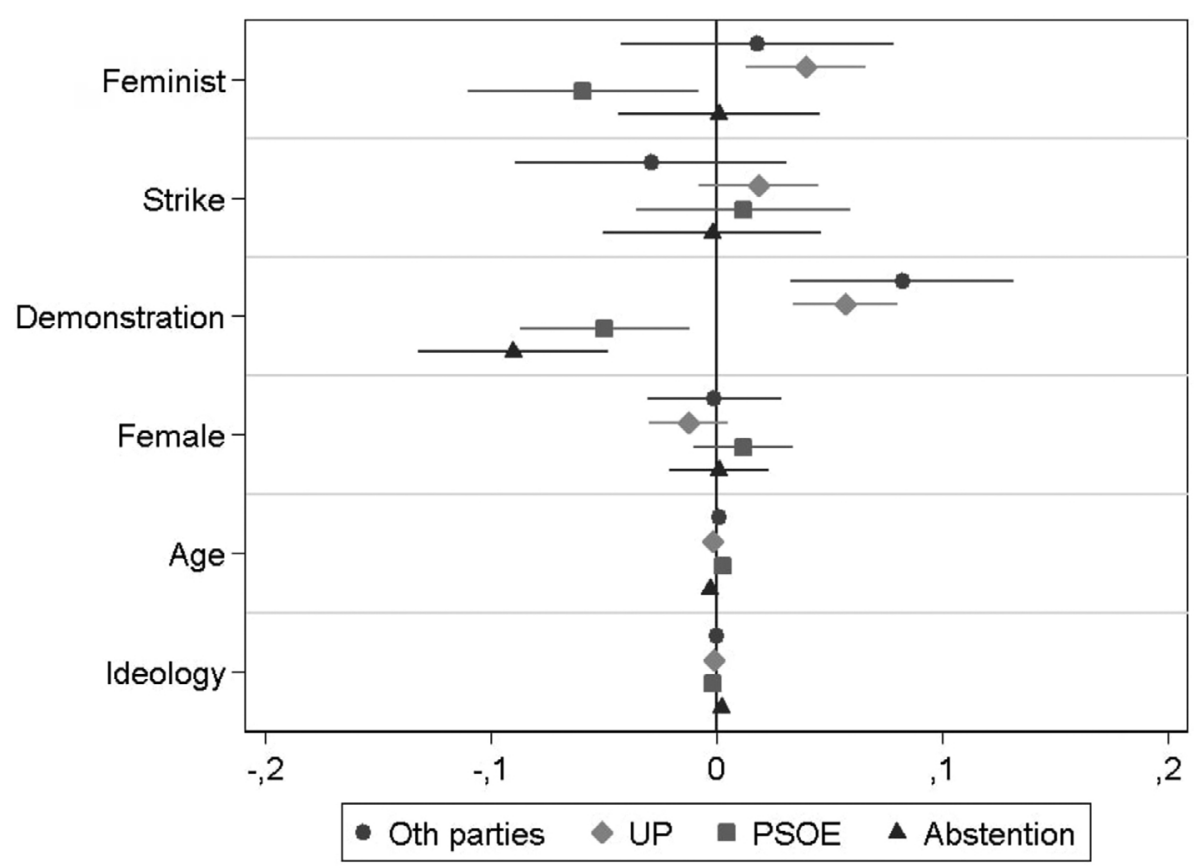

Figure 8. Coefficients from multinomial logistic regression on feminist protest outcomes. Dependent variable: electoral performance. Categories at legend. Own elaboration from CIS 3173 and 3210.

In Figure 9 a similar regression model' coefficients are exposed. In this case, the main independent variable is the consideration of citizens to be capable to be influential in liberal democratic systems and institutions. That is to say, to be politically effective. One can observe UP's voters are both considering themselves significantly more feminist and politically effective. In addition, those who opt for electoral abstention consider themselves not able to influence. Although with little significance, it must be highlighted that women are more likely to abstain rather than to vote UP. 


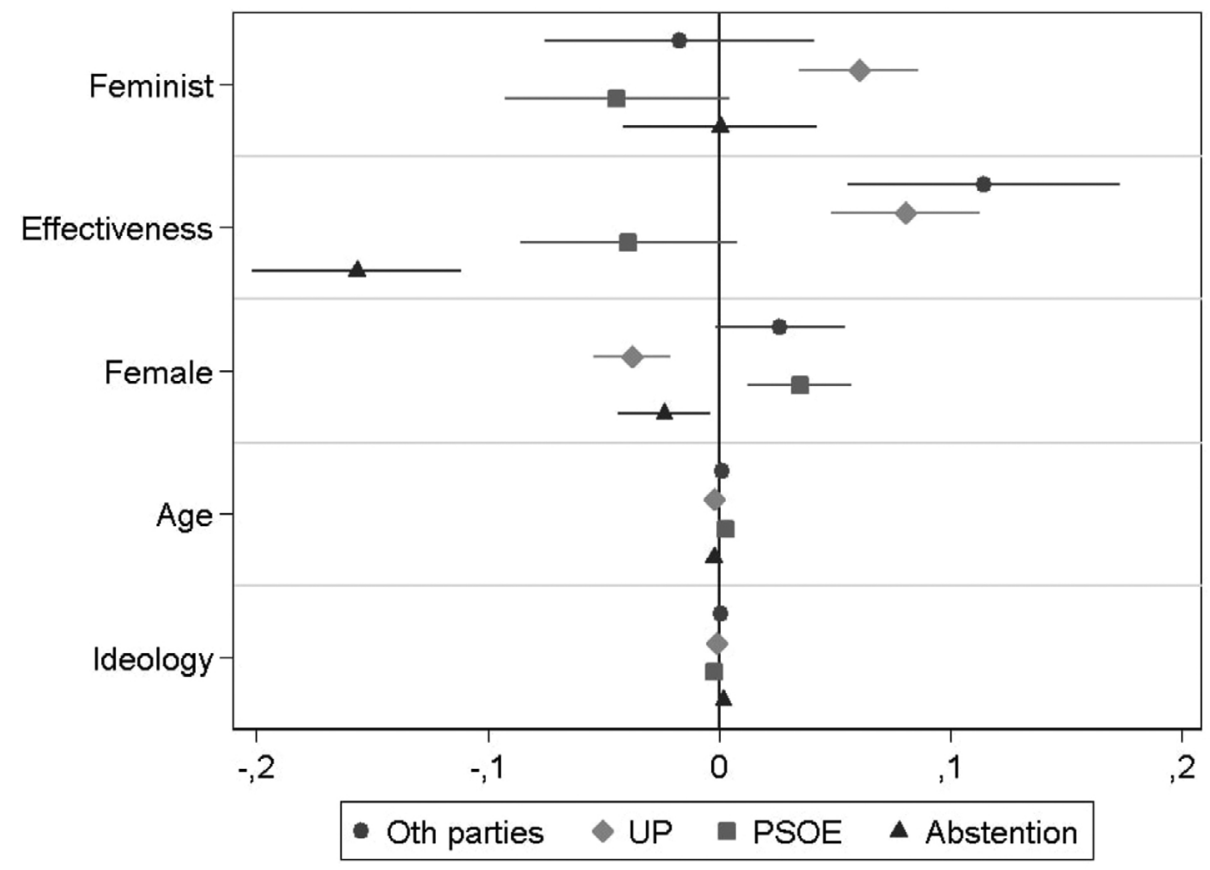

Figure 9. Coefficients from multinomial logistic regression on feminist effectiveness outcomes. Dependent variable: electoral performance. Categories at legend. Own elaboration from CIS 3156 and 3226.

\section{Conclusion}

Throughout data analysis we have satisfactorily tested H1 and H2. Not only there is a real growth of protest politics and feminist ideologization in Spanish politics but also it is closely related and feedbacking. In addition, we find substantial evidence supporting both $\mathrm{H} 3$ and H4. Political disaffection within feminist movement is not causing disengagement with political system nor the emergence of anti-politics. Instead, some sort of anti-establishment politics is also happening within feminism channelized by a new political party driving effectively feminist's demands.

That can be explained under classical Hirschman's (1970) framework. Feminist movement has stopped being loyal to Spanish party system and stopped supporting political party not only representing mainstream politics but also feminist-mainstream politics, PSOE. Nonetheless, the decision the majority of feminists have made is not to exit, finishing any kind of participation within liberal democratic regime, but to express their voice. That is to say, since the political system is no longer satisfying feminists demands, they have started to send inputs in the form of electoral change.

Nonetheless, some cautions are needed in this analysis. The emergence of a critical feminism challenging institutional feminism paradigm is limited by effectiveness and slightly by gender. So, we can expect those women with less cultural capital and political resources to disengage more easily rather than participate in radical shifts towards critical feminism. Undoubtedly, this is an issue that has not been solved within the limits of this study and would deserve further research.

To sum up, on the feminist dilemma about participating in inegalitarian liberal democracies or to suffer social-labor inequality without their political participation, they have opted for the radical democratic way. Feminist movement has not stopped backing 
democracy as political regime but its ruling elites and current institutions. Their present goal is not to substitute liberal democracy but to deepen and democratize it.

\section{Bibliography}

Abowitz, Kathleen Knight \& HaRnish, Jason (2006). Contemporary discourses of citizenship. Review of educational research, 76(4), 653-690.

Balaguer Callejón, María Luisa (2019). El feminismo de hoy. Paradigma. Revista universitaria de cultura, 140-143

BICKFORD, SuSAn (1997). Anti-anti-identity politics: Feminism, democracy, and the complexities of citizenship. Hypatia, 12(4), 111-131.

CARAWAY, TERI L. (2004). Inclusion and democratization: class, gender, race, and the extension of suffrage. Comparative Politics, 443-460.

CAMPILlo, InÉs (2019). 'If we stop, the world stops': the 2018 feminist strike in Spain. Social Movement Studies, 18(2), 252-258.

Centella Gómez, José Luis (2018). La huelga feminista del próximo 8 de marzo. El Siglo de Europa, (1231), 10.

Cornwall, Andrea \& Goetz, Anne Marie (2005). Democratizing democracy: Feminist perspectives. Democratisation, 12(5), 783-800.

EASTON, David (1965). A System Analysis of Political Life. Wiley: New York.

Fallon, Kathleen M; Swiss, Liam \& Viterna, Jocelyn (2012). Resolving the democracy paradox: Democratization and women's legislative representation in developing nations, 1975 to 2009. American Sociological Review, 77(3), 380-408.

Fraser NANCY (1992). Rethinking the Public Sphere: A Contribution to the Critique of Actually Existing Democracy. In Calhoun, C. (ed.). Habermas and the Public Sphere. Cambridge, MA: MIT Press.

Fraser, Nancy; Arruzza, Cinzia \& Bhattacharya, Tithi (2019). Feminism for the 99\%. Verso.

GAHETE MuÑoz, SoRAYA (2017). Las luchas feministas. Las principales campañas del movimiento feminista español (1976-1981). Investigaciones feministas: papeles de estudios de mujeres, feministas y de género, 8 (2), 583-601.

García, BeAtriz; Alabao, Nuria \& PÉREZ, MARisa (2018). Spain's feminist strike'. New left review, 110, 35-37.

Hirschman, Albert 0. (1970). Exit, Voice and Loyalty. Cambridge, Mass.: Harvard University Press.

KYMLICKA, W (1995). Multicultural citizenship: A liberal theory of minority rights. Clarendon Press.

Lister, Ruth (1997). Citizenship: Towards a feminist synthesis. Feminist review, 57(1), 28-48.

Menser, Michael (2018). We Decide! Theories and Cases in Participatory Democracy. Temple University Press. 
Moriana Mateo, Gabriela (2018). Y después de la huelga feminista del 8M, qué. Revista de treball, economia i societat, (88), 1-8.

Mouffe, Chantal (2013). Feminism, citizenship, and radical democratic politics. In Butler, Judith \& Scott, Joan J. (Eds.) Feminists theorize the political. Routledge: 387-402

Pateman, Carole (1988) The Sexual Contract, Stanford University Press.

Pateman, Carole (1989) The Disorder of Women: Democracy, Feminism and Political Theory. Stanford: Stanford University Press.

Phillips, Anne (1992). Must feminists give up on liberal democracy? Political studies, 40, 68-82.

Portos, Martin (2019). Divided We Stand, (Oftentimes) United We Fight: Generational Bridging in Spain's Feminist Movement and the Cycle of Antiausterity Mobilizations. American Behavioral Scientist, 1447-1468.

Watkins, Susan (2018). Which feminisms? New Left Review, (109), 5-76.

Young, IRIS MARIon (1990). Justice and the Politics of Difference. Princeton University Press. 